\title{
NUTRITIONAL FACTORS INFLUENCING IMPROVEMENT OF MILK AND MEAT QUALITY AS WELL AS PRODUCTIVE AND REPRODUCTIVE PARAMETERS OF CATTLE**
}

\author{
Lj. Sretenović ${ }^{1 *}$, S. Aleksić ${ }^{1}$, M.P. Petrović ${ }^{1}$, B. Miščević ${ }^{2}$ \\ ${ }^{1}$ Institute for Animal Husbandry, Belgrade-Zemun, Serbia \\ ${ }^{2}$ University Mega Trend, Belgrade, Serbia \\ *Corresponding author, e-mail: lilisret@ptt.yu \\ **Plenary invited paper. Research financed by the Ministry of Science of Republic of Serbia, \\ Project TR 6858
}

\begin{abstract}
Consumers are becoming more aware of the relationships between diet and health and this has increased consumer interest in the nutritional value of foods. This is impacting on the demand for foods which contain functional components that play important roles in health maintenance and disease prevention. Vitamin E, organically bound selenium and betacarotene are important antioxidant components of animal and human diets, and also unsaturated fatty acids and yeast and their roles in animal and human health and immune function are indispensable. The present review paper will discuss these nutrients in relation to antioxidant and health considerations and draw conclusions as to vitamin and mineral supplementation needs.
\end{abstract}

Key words: vitamine E, organically bound selenium, unsaturated fatty acids, betacarotine, yeast cells

\section{Introduction}

The stress is the biggest and most important problem of modern life style and question is how to solve that and overcome it. The main goal is to insure good health of animals by proper nutrition and supplying human body with essential protective nutrients through animal products i.e. milk and meat.

Oxidative stress occurs when the production of reactive oxygen metabolites (ROM) exceeds the capacity of the antioxidant system of the cell, tissue, or body. Normal cell metabolism, environmental insults, and 
inflammatory responses produce compounds called ROM or free radicals. The major ROM found in biological systems are superoxide, hydrogen peroxide, hydroxyl radical, and fatty acid radicals. These compounds can react with enzymes, cell membranes, and DNA causing cell damage or cell death. Because ROM are toxic to cells, the body has developed a sophisticated antioxidant system that relies on antioxidant nutrients

The prevalence and severity of several important health disorders in dairy cows including retained fetal membranes, udder edema, and mastitis appear to be related to oxidative stress. In addition, antioxidant nutrients can affect milk quality. Milk quality is usually defined in terms of mastitis (Sretenović et al. 2006). Milk with a low somatic cell count (SCC) and visibly normal appearance (no clots) is considered high quality.

Certain nutrients serve as antioxidants or are components of antioxidant enzymes. Antioxidants include vitamins $\mathrm{C}$ and $\mathrm{E}$, carotenoids, and antioxidant enzymes containing $\mathrm{Se}, \mathrm{Cu}, \mathrm{Mn}, \mathrm{Fe}$ or $\mathrm{Zn}$. Stress conditions that generate free radical production can be classified as nutritional (e.g., high PUFA and or excesses of certain minerals and vitamins), environmental (e.g., temperature and humidity) and internal (e.g., bacterial, viral and fungal diseases). Under commercial ruminant production conditions, vitamin and mineral allowances higher than NRC 2001 (National Research Council) requirements may be needed to allow optimum performance.

\section{Vitamin E}

Vitamin $\mathrm{E}$ is one of very important dietary component contributing to natural antioxidant defences in tissues. At the cellular level, vitamin $\mathrm{E}$ is mainly distributed in membrane structures and plasma lipoproteins due their highly lypophilic characteristics. Also, vitamin E has a great role in prevention of mastitis. Mastitis is still an extremely prevalent and expensive problem for dairy farmers. Substantial amounts of ROM are produced by certain types of immune cells during an inflammatory response to assist those cells in killing the pathogen. When those cells contain adequate amounts of antioxidants, the concentrations of ROM are kept in check, which allows those cells to kill additional bacteria before the immune cell is killed. When antioxidant capacity is limited, the lifespan of those immune cells is reduced and the infection can become established or severity of the infection can increase. Supplemental vitamin $\mathrm{E}$ and/or Se has been shown to reduce prevalence and severity of mastitis and reduce SCC (Sretenović et al. 2007a).

Baldi et al. (2000) supplemented cows with 1,000 or 2,000 IU vitamin E 
starting $14 \mathrm{~d}$ prepartum through $7 \mathrm{~d}$ postpartum and reported significant reduction in days open in cows fed 2,000 IU/d (111 vs $84 \mathrm{~d}$ ) and fewer services per conception (1.3 vs. 2.2). Kim et al. (1997) used 120 Holstein cows to test the effects of injecting $500 \mathrm{IU}$ vitamin E and $40 \mathrm{mg}$ Se at $20 \mathrm{~d}$ prepartum on reproductive performance. The combination of vitamin $\mathrm{E}$ and Se significantly reduced the incidence of retained placenta (30 vs $13.3 \%$ ) and days to first service (103 vs $60 \mathrm{~d}$ ).

It is well established that vitamin E supplementation of the diets of meatproducing animals effectively elevates muscle vitamin E levels, and lowers the susceptibility of muscle and, ultimately, meat products to lipid oxidation and the onset of flavour defects In beef, significant improvements in color stability following dietary vitamin $\mathrm{E}$ supplementation have been reported and are attributed to a vitamin E.

Meat with elevated levels of either and probably both of these antioxidant vitamins possesses greater stability of oxymyoglobin and lipid, which results in less discoloration and rancidity. Vitamin E would seem to be the most practical since it is administered dietetically. Accumulating data suggests that higher intakes of vitamin E during the periparturient period ( $>1000 \mathrm{IU} / \mathrm{d})$ may be beneficial. Weiss et al. (1997) reported that feeding 4000 IU of supplemental vitamin E/day during the last 14 days of the dry period reduced clinical mastitis and new infections at calving compared with cows fed $1000 \mathrm{IU} / \mathrm{d}$.

\section{Organically bound selenium}

Se and certain nutrients act as antioxidants or are components of antioxidant enzymes and have a direct effect on oxidative stress. Selenium, a well-known antioxidant, may reduce the risk of certain types of cancer and heart disease, as well as enhance the body's ability to fight infections. Vitamin E and Se are important components of the antioxidant defense system of living tissues. Vitamin $\mathrm{E}$ has the capacity to quench free radicals capable of initiating and propagating lipid oxidation, and the Se-containing antioxidant enzyme glutathione peroxidase (GSH-Px) catalyses the decomposition of lipid hydroperoxides into less-reactive products. Selenium as part of glutathione peroxidase (GSH-Px) is the $2^{\text {nd }}$ line of defense as the enzyme destroys peroxides and hydroperoxides.

Selenium is needed to maintain good health of cattle. Cows fed inadequate amounts of selenium are at higher risk for retained fetal membranes and mastitis. Milk selenium concentrations are approximately twice as high when selenium yeast is fed compared with selenite or selenate. 
Higher milk selenium concentrations would result in increased intake of selenium by humans consuming dairy products that may have positive human health implications (Sretenović et al., 2005a; Sretenović et al., 2007b). Many researchers have established that addition of selenium through diets can increase its concentration in milk.

In research by Popović and Vukić Vraneš (1998), adding of organically bound selenium (Sel-Plex 50) in combination with live cells of yeast and organically bound zinc (Bioplex $\mathrm{Zn}$ ) in diets for cows for duration of 100 days caused increase of milk quantity by $171 \mathrm{~kg}$ or $7.6 \%$, milk fat by $6.14 \mathrm{~kg}$ or $7.8 \%$, and protein by $7.63 \mathrm{~kg}$ or $10.42 \%$ ( $\mathrm{P}<0.05)$. In lactating cows higher percentage of mastitis was established in control $(9 \%)$ compared to trial group $(4,6 \%)$ which can be attributed to the effect of treatment.

In research by Sretenovic et al. (1999a), the effect of addition of organically bound selenium and other micro elements in comparison to inorganic forms in relation 30:70\% on productive and reproductive traits of dairy cows was investigated. Pregnancy in trial group compared to control was higher by $10.34 \%$ and was 64 and $58 \%$. In paper by same authors Sretenović et al. (1994) effects of organically bound selenium in form of selenium methionine was compared to inorganic selenium form in diets for cows. In trial group the quantity of milk increased by $0.83 \mathrm{~kg}$ or $3.5 \%$ $(\mathrm{P}<0.05)$, and content of selenium in blood increased by $2.1 \%$. Mentioned results demonstrate the justification for introduction of organically bound selenium in diets, since this is the most natural way for its introduction in the human organism.

In muscle tissue, the antioxidant functions of vitamin $\mathrm{E}$ and Se persist after slaughter and delay the onset of oxidation reactions in meat and meat products. These antioxidant functions are important because the oxidation of muscle lipids after slaughter can adversely affect the flavour and nutritive value of fresh, frozen, and cooked meat and meat products.

Muscle Se levels have been shown to respond to dietary $\mathrm{Se}$ supplementation in beef cattle (Ekholm et al., 1991). Ekholm et al. (1991) reported a linear increase in bovine muscle Se concentration where the dietary Se concentrations in the feed ranged from 0.03 to $0.40 \mathrm{mg} / \mathrm{kg} \mathrm{DM}$.

\section{Beta carotene}

Beta carotene is a member of the carotenoid family which are characterised by their antioxidant properties and appear to have cancer preventative properties. It is important because is a precursor to vitamin A which means that it is converted by the body into the vitamin. Studies in 
humans have shown that a high intake of beta-carotene in the diet is associated with a reduced risk of chronic diseases, such as coronary heart disease and cancer.

Vitamin $A$ and $\beta$-carotene have important roles in protection against numerous infections including mastitis.

Jukola et al. (1996) reported positive effects when cows were diets that approximately met NRC requirements for vitamin A and supplemented with $300 \mathrm{mg} / \mathrm{d}$ of B-carotene. Supplementation occurred during the dry period and early lactation. Jukola et al. (1996) suggested that plasma concentrations of beta carotene in dairy cows should be $>3 \mathrm{mg} / \mathrm{L}$ to optimise udder health. Current NRC (2001) requirement for vitamin A is approximately 70,000 IU/d.

Most of the researchers agree with the fact that role of beta carotene in reproduction of high yielding dairy cows is irreplaceable and that application of beta carotene should be initiated in dry off period (Sretenović et al. 2005b).

Results obtained by Sretenovic et al. (1999b) indicate the same conclusions. Results of the factorial trial $(3 \times 2)$ are presented; trial was carried out on three groups of cows: dried off cows, cows immediately after calving and cows with reproductive problems - with cysts on ovaries or prolonged service period. Cows in trial received 300mg beta carotene, 50 000IJ of vit.A and $100 \mathrm{mg}$ of vit.E. It can be noticed that if application of beta carotene starts in dry off period service period is considerably shortened (from 93.46 to 78.05 days) and at the same time insemination index is decreased (from 2.94 to 1.94). In the group of cows with reproductive problems decrease of insemination index and shortening of service period were also registered. In all investigated trial groups service period was shorter by 15,9 and 26 days, which can cause significant rationalizations in dairy production.

\section{Yeast cells}

In order to overcome problems in dry period and early lactation it is recommended to use some feed additives whish are a group of feed ingredients that can cause a desired animal response in a non-nutrient role such as $\mathrm{pH}$ shift, growth, or metabolic modifier (Hutjens, 1991).Response refers to expected performance changes the user could expect or anticipate when a feed additive is included. Several examples are listed below.

Higher milk yield; greater dry matter intake; stimulate rumen microbial synthesis of protein and volatile fatty acid production; increase digestion in 
the digestive tract; stabilize rumen environment and $\mathrm{pH}$; improve growth (gain and/or feed efficiency); minimize weight loss; reduce heat stress effects; improve health (Sretenovic et al., 2006). Their nutritive value is high; they are rich in enzymes, fatty acids, vitamin B complex, unknown growth factors and amino acids (more than $40 \%$ of total dry matter).

Objective of investigation researchers Sretenović et al. (2007c) was to determine the effects of application of the yeast cells in combination with probiotic bacteria and enzymes. Trial group received $10 \mathrm{~g}$ of preparation daily during the stage of high gravidity and it lasted until $60^{\text {th }}$ day of lactation. The difference between trial and control group was $2.57 \mathrm{~kg} 4 \%$ fat corrected milk or $10.86 \%$,but there was no differences in milk quality. The effect of this preparation on somatic cell count was show that trial group had smaller count of somatic cells for 7.3 percent points (173.000 vs.161.200), what indicated better health status of cow's udder.

The trial conducted by $\mathrm{Wu}$ Zilin (1996) demonstrated that inclusion of yeast culture in the daily ration of dairy cows increased dry matter intake $3.94 \%$, milk yield $4.04,3.5 \% \mathrm{FCM} 7.07 \%$, milk fat percent $5.77 \%$ and significantly increased the amount of milk produced, but had minor effect on milk constituents.

\section{Unsarurated fatty acids}

What are omega-3 essential fatty acids? Omega-3 is a group of polyunsaturated fatty acids which are commonly found in milk, oily fish and some vegetables. Omega- 3 and omega- 6 are considered 'essential' to health because the human body cannot produce them and they must be obtained through a good diet. It is important that there is an adequate balance of omega- 3 and omega- 6 in the diet, the latter of which is mainly found in plant oils. The balance in the average west diet is around 1:10, while a ratio of $1: 3$ is recommended with a higher proportion of omega-3 (Simopolous, 2002). Omega 3 fatty acids help decrease LDL, decrease high blood pressure and irregular heart beats. People who eat a high Omega 3 diet have $50 \%$ less heart attacks. They also had a decreased cancer risk along with many other decreased health problems (Sretenović et al., 2004). Extrapolation from animal studies suggests that humans may need to consume about $3 \mathrm{~g}$ of CLA per day.

There are two main groups of omega-3 which have different nutritional properties - short-chain omega-3 which are mainly found in milk and plants and long-chain omega-3 which are mainly found in oily fish like mackerel, salmon and herring. Milk can provide nutritionally important short-chain 
omega-3_(alpha-linolenic acid or ALA) but relatively little long chain omega-3 (eicosapentaenoic acid (EPA) and docosahexaenoic acid (DHA)). The latter are known to help maintain heart health as well as improving brain and vision development in foetuses and infants.

Conjugated linoleic acid (CLA) is a naturally occurring component of ruminant milk fat and meat with potent cancer-fighting properties.

The concentration of CLA in bovine milk is strongly influenced by diet of the cow. Manipulation of the animal's diet can result in up to a 8 to 10fold increase in the concentration of CLA in milk. Consumption of CLA enriched milk could provide considerable benefits for human health. As consumers are becoming more conscious of the relationship between food and health, CLA may prove to be "designer milk" or "functional food" with substantial potential and benefit.

Forages such as grass and clover contain a high proportion (50-75\%) of total fatty acids as linolenic acid, an omega-3 PUFA. Exploiting herbage as a source of omega-3 PUFA is an important nutritional strategy for enhancing the content of omega-3 PUFA. The fat that is present from the grass diet is full of Omega 3 fatty acids. Over $60 \%$ of the fatty acids in green forages are Omega 3 fatty acids. Grass fed beef has 2-4 times the Omega 3 levels of grain fed beef. Another richly available benefit in grass fed beef is conjugated linoleic acid (CLA), another good fat. CLA has 3-5 times higher levels in grass fed beef than grain fed beef. CLAs are also stored in the fat of grass fed beef. The cis-9, trans-11 isomer of CLA is formed during biohydrogenation of linoleic acid in the rumen. Consequently, ruminants are the only source of 'natural' CLA.

\section{Conclusion}

Manipulation of the animal's diet can result in increase in the concentration of some essential nutrients in milk and meat and could provide considerable benefits for human health.

As consumers are becoming more conscious of the relationship between food and health, vitamin E, organically bound selenium, betacarotene, omega-3 and CLA may prove to be "designer milk", "designer meat" or "functional food" with substantial potential and benefit. 


\title{
ISHRAMBENI FAKTORI KOJI UTIČU NA POBOLJŠANJE KVALITETA MLEKA I MESA KAO I PRODUKTIVNIH I REPRODUKTIVNIH PARAMETARA KOD GOVEDA
}

\author{
Lj. Sretenović, S. Aleksić, M.P. Petrović, B. Miščević
}

\section{Rezime}

U novije vreme sve veći značaj dobijaju programi tkz. funkcionalne hrane animalnog porekla koja ima za cilj da obezbedi osnovne ishrambene potrebe kao i neophodne hranljive materije koje će preventivno i terapeutski delovati na pojavu bolesti. U radu je na revijalan način predstavljena mogućnost promene sadržaja pojedinih esencijalnih supstanci (vitamina, organskih formi pojedinih mikrelemenata, nezasićenih masnih kiselina) putem ishrane goveda, što dovodi do povećanja njihovog sadržaja u mleku i mesu. Takođe, predstavljene su ishranbene preporuke koje su rezultat savremenih istraživanja čija primena utiče na popravljanja proizvodnih i reproduktivnih performansi životinja.

Ključne reči: vitamin E, organski vezan selen, nezasićene masne kiseline, betakarotin, ćelije kvasca

\section{References}

BALDI, A., SAVOINI G., PINOTTI L., MONFARDINI E., CHELI F. AND DELLORTO V. (2000): Effects of vitamin E and different energy sources on vitamin $\mathrm{E}$ status, milk quality and reproduction in transition cows. J. Vet. Med. Assoc. 47:599.

EKHOLM, B.P., VARO, P., ASPILA,P., KOIVISTOINEN, L. SYRJALAQVIST (1991): Transport of beef Se to different tissues in bulls.Br.J. Nutr. 66: 49-55.

HUTJENS, F.M. (1991): Feed additives. Vet Clinics North Am.: Food Animal Practice. 7:2:525.

JUKOLA E., HAKKARAINEN J., SALONIEMI H., SANKARI S. (1996): 
Blood selenium, vitamin E, vitamin A and beta-carotene concentrations and udder health, fertility treatments and fertility. Journal of Dairy Science, 79, 838-845.

KIM H.S., LEE J.M., PARK S.B., JEONG S.G., JUNG J.K. AND IM. K.S. (1997): Effect of vitamin E and selenium administration on the reproductive performance in dairy cows. Asian-Australasian J. An. Sci. 10:308.

NRC. 2001. Nutrient Requirements of Dairy Cattle. (7th rev. ed.) Natl. Academy Press, Washington, D.C.

POPOVIĆ Z., VUKIĆ VRANEŠ M. (1998): Organski vezani mikroelementi i žive ćelije kvasca u ishrani muznih krava. Farmer, br.12, 9.

SIMOPOULOS A. P. (2002): 'The importance of the ratio of omega6/omega-3 essential fatty acids.' Biomed. Pharmacother, 68(8): 365-379

SRETENOVIĆ LJ., ADAMOVIĆ M., JOVANOVIĆ R., STOIĆEVIĆ LJ., GRUBIĆ G., NIKOLIĆ V. (1994): Ispitivanje organski veyanog selena u obrocima visokomle;nih krava u ranoj laktaciji. VII Savetovanje veterinara Srbije, Zbornik kratkih radova, str. 52, Zlatibor.

SRETENOVIĆ LJ., JOVANOVIĆ R., ADAMOVIĆ M., MILOŠEVIĆ M. (1999a): Organically tied selenium in high yielding cows nutrition. Biotehnologija u stočarstvu, 69-76.

SRETENOVIĆ LJ., JOVANOVIĆ R., ADAMOVIĆ M., MILOŠEVIĆ M. (1999b): The influence of betacarotene on reproductive and production traits in high yielding dairy cows. The 5th International Symposium "New Trends in Breeding Farm Animals". Biotehnologija u stočarstvu, 77-87.

SRETENOVIĆ LJ. (2004): Noviji aspekti uticaja ishrane krava na količinu i sastav mleka. Simpozijum " Mleko i proizvodi od mleka stanje i perspektive« 63-73, Zlatibor, 2004.

SRETENOVIĆ LJ. (2005a):Dobijanje mleka sa osobinama funkcionalne hrane putem ishrane mlečnih krava. Međunarodni simpozijum tehnologije hrane za životinje »Obezbeđenje kvaliteta«, Vrnjačka Banja 30 maj-3 jun.149-157.

SRETENOVIĆ LJ., PETROVIĆ M.M. (2005b): Effect of nutrition on improvement of reproductive performances of high yielding cows. Journal of Animal Science, Vol.XLII, Sofia, 5, 9-15.

SRETENOVIĆ LJ., PETROVIĆ M.M., KATIĆ V. (2006):Uticaj pojedinih dodataka hrani u cilju popravljanja zdravstvenog stanja vimena krava. Simpozijum»Mleko i proizvodi od mleka«, Tara, 21-25 maj, Zbornik radova, 31.

SRETENOVIĆ LJ., PETROVIĆ M.M., ALEKSIĆ S., STOJANOVIĆ LJ. (2007a): Effects of additives in high yielding dairy cows rations in order to 
improve milk production. Journal of mountain agriculture on the Balkans, Vol. 10, No 3, 388-403.

SRETENOVIĆ LJ., ALEKSIĆ S., PETROVIĆ M.M., PETROVIĆ M.P., STOJANOVIĆ LJ. (2007b): Application of modern technology of nutrition in high yielding cows in dry period and early lactation. Biotechnology in Animal Husbandry, 29-40.

SRETENOVIĆ LJ., PETROVIĆ M.M., PETROVIĆ M.P., ALEKSIĆ S. (2007c): Primena savremenih biotehnologija u cilju povećanja količine i kvaliteta mleka .Savrenena poljoprivreda, Vol.56, 24-2, 31-36.

WEISS W. P., HOGAN J. S., TODHUNTER D. A. AND SMITH K. L. (1997): Effect of vitamin E supplementation in diets with a low concentration of selenium on mammary gland health of dairy cows. j. dairy sci. 80:1728- 1737.

WU ZILIN (1996): Effects of yeast culture on milk yield and milk composition. International yeast culture dairy research. 3:214-215. 